\title{
Koleszterincsökkentés idősek, szívelégtelenek, veseelégtelenek, alacsony kockázatúak speciális alcsoportjaiban a nemzetközi ajánlások nyomán
}

\author{
Bajnok László
}

Pécsi Tudományegyetem, Klinikai Központ, I. sz. Belgyógyászati Klinika, Endokrinológiai és Anyagcsere Tanszék, Pécs

Levelezési cím:

Prof. dr. Bajnok László, 7624 Pécs, Ifjúság út 13. E-mail: bajnok.laszlo@pte.hu

A gyógyszeres koleszterinszint-csökkentés általános hatékonyságának és biztonságosságának elfogadása kiviláglik a 2019-es európai dyslipidaemiaajánlás szélesedő javallati köréböl és mélyülő célértékeiböl. Vannak azonban olyan betegcsoportok - így a nem megtartott EF szívelégtelen koronáriabetegek vagy súlyosan veseelégtelenek -, ahol a rossz kardiovaszkuláris prognózist a statinok nem tudják érdemben javítani. Az idősek szekunder prevenciója tekintetében az európai irányelvek - lényegében - nem diszkriminatívak, de az elsődleges megelözés terén konzervatív tendencia érvényesül, annak ellenére, hogy a rendelkezésre álló evidenciák arra utalnak, hogy sem a relatív hatás, sem a kockázat nem különbözik érdemben a kevésbé idősekhez képest. Ez a megítélés a folyamatban lévő célzott statinos vizsgálatok hatására változhat. Az élethosszra vetített kockázat koncepciójának elötérbe kerülésével az alacsony kockázatúak nem magas koleszterinszintjének gyógyszeres csökkentése is megfontolandóvá vált.

Kulcsszavak: koleszterinszint-csökkentés, idősek, veseelégtelenség, szívelégtelenség, alacsony kockázatúak, irányelvek, statinterápia, ezetimib

Cholesterol reduction in special subgroups of elderly, heart failure, renal failure, low cardiovascular risk The acceptance of the overall efficacy and safety of cholesterol lowering drugs is evident from the broadening indications and deepening target values of the 2019 European Dyslipidemia Guidelines. However, there are groups of patients, such as with non-preserved EF ischemic heart failure or severe renal insufficiency, where statins cannot significantly improve poor cardiovascular prognosis. With regard to the secondary prevention of the elderly, the European guidelines are essentially non-discriminatory, but there is a conservative trend in primary prevention, although the available evidences suggest that neither the relative effect nor the risk are significantly different from that of the less elderly. This concept may change by the results of ongoing dedicated statin trials. With the advent of the lifelong risk concept, reduction of non-high-cholesterol levels by medicines of low risk individuals have also become to be considered.

Keywords: cholesterol lowering, elderly, renal failure, heart failure, low risk, guidelines, statin therapy, ezetimibe

\section{Bevezetés}

Az Európai Kardiológiai Társaság (ESC) és az Európai Ateroszklerózis Társaság (EAS) 2019-es dyslipidaemiaajánlása alapján igen nagy kardiovaszkuláris (KV) kockázatú kategóriába sorolódnak:
- az ateroszklerotikus szekunder prevenciót igénylők;

- azon diabéteszesek, akiknél célszervkárosodás vagy legalább három major kockázati tényező van, illetve húsz évnél régebben fennálló 1-es típusú diabéteszben szenvednek, továbbá

- $30 \mathrm{ml} / \mathrm{min} / 1,73 \mathrm{~m}^{2}$ alatti eGFR-üek;

A kézirat 2020. 09. 01-jén érkezett a szerkesztőségbe, 2020. 10. 05-én került elfogadásra. 
- 10\%-ot elérő SCORE-értéküek, illetve

- azon heterozigóta familiáris hypercholesterinaemiások (FH-sok), akiknél egyéb major kockázati tényező is fennáll (1).

Nagy kockázatúak a súlyos hypercholesterinaemiások (LDL-C $\geq 4,9 \mathrm{mmol} / \mathrm{l}$ ) vagy a 3 . fokozatú hipertóniások, a major kockázati tényezővel nem terhelt $\mathrm{FH}$ sok, azon diabéteszesek, akiknél célszervkárosodás nincs, de legalább tíz évnél régebben fennáll a diabétesz vagy major kockázati tényező is jelen van; illetve a 30 és $59 \mathrm{ml} / \mathrm{min} / 1,73 \mathrm{~m}^{2}$ közötti eGFR-üek és az 5-9 közötti SCORE-értéküek. Mérsékelt a kockázat 1-4\% SCORE mellett vagy fiatal(abb) diabéteszesek esetén (1-es típusnál 35 év alattiak, 2-es típusnál 50 évesnél fiatalabb), akiknél tíz évnél rövidebb ideje áll fenn a diabétesz és nincs egyéb kockázati tényező. Az európai ajánlás koleszterincsökkentő - az LDL-C-szintből és a kardiovaszkuláris kockázat együtteséből előálló - javallatát (erősségét) az 1. táblázat, a kockázati kategóriák szerinti LDL-C-célértékeket a 2. táblázat, az ezek elérésére irányuló gyógyszeres stratégiát pedig a 3. táblázat összegezi (1). Az alábbiakban négy olyan körülményt - állapotot, illetve társbetegséget - veszünk számba, amelyek esetén a koleszterincsökkentő(k) alkalmazása, illetve módja kevéssé egyértelmü.

\section{Gyógyszeres koleszterincsökkentés 75 év felett}

Koleszterin, annak csökkentése és

a KV-kockázat időseken -

a klinikai vizsgálatok alapján

Bár időseknél a rendelkezésre álló adatok szűkösebbek és a mellékhatások miatti félelmek fenyegetőbbek, az evidenciák arra utalnak, hogy sem a relatív hatás (2), sem a kockázat (2-4) nem különbözik érdemben a kevésbé idősekhez képest. A Cholesterol Treatment Trialists' Collaboration 14 483, 75 év feletti, zömmel manifeszt ateroszklerotikus beteg metaanalízise során bár az életkor növekedésével a koronária protektív hatás - szemben a stroke-éval - részlegesen csökkent, összességében a fiatalabbakhoz teljesen hasonlatos mértékünek adódott a statinok hatása: a major KV-kockázat $21 \%$ csökkenése az LDL-C minden $\mathrm{mmol} / \mathrm{l}$ mértékű redukciójával (2). A dializáltakon vagy szívelégteleneken végzett vizsgálatok kizárása után a kockázat relatív csökkentése szempontjából nem volt érdemi hatása annak, hogy volt-e ismert KV-betegsége a 75 év felettinek. Mindez különösen azért érdekes, mert az epidemiológiai vizsgálatok szerint időseken a plazmakoleszterin és a KV relatív kockázat közötti kapcsolat kevésbé erős (5) vagy - más vizsgálatok szerint - épp fordított $(6,7)$. (A véletlen besorolásos ellenőrzött nagy vizsgálatokat semmi nem helyettesíti, és ezek adják a legmagasabb szintű választ.) És ez az ellentmondás nem magyarázható meggyőzően a statinok pleiotrop hatásaival, mert az IMPROVE-IT egy posthoc elemzé- sében az ezetimibbel elért koleszterincsökkentés is hasonló eredményt hozott (4). Ez egyben azt is jelentette, hogy az akut koronáriaszindrómát 75 év felett elszenvedőkön az abszolút kockázatcsökkenés nagyságrendnyivel nagyobb intenzívebb koleszterincsökkentés mellett, mint fiatalabbakon ( $8,7 \%$ vs. $0,8 \%)$; így már hat ilyen 75 év feletti beteg ötévi kezelése elegendő egy kardiovaszkuláris esemény megelőzéséhez (NNT). Egy nagy megfigyeléses vizsgálat is hasonlónak találta az intenzív statinkezelés relatív mortalitáscsökkentő hatását 75 év felett és alatt (8). Tehát időseknél a hatás/ mellékhatás arány nem kisebb, hanem nagyobb.

Kevesebb evidencia áll rendelkezésre a manifeszt ateroszklerotikus betegséggel nem terhelt idősek statinkezelésével kapcsolatban $(2,9)$. Bár az epidemiológiai vizsgálatok sora (ugyan nem mindegyik) pozitív, nagy várakozás előzi meg a folyamatban lévő nagy primer prevenciós studykat. Ilyen a 2022 körül várható eredményü, 70 év feletti (nagyjából) egészségesek esetében $40 \mathrm{mg}$ atorvastatin hatását elemző ausztrál STAREE (10) és a 2023 után várható, 75 éves korban felfüggesztett statin következményeit felmérő francia SITE/SAGA (11). Tanulságos ugyanakkor a közelmúltban közölt EWTOPIA 75, amelyben - bár a tervezés és kivitelezés nem volt optimális - magasabb koleszterinü (átlag LDL-C: 4,3 mmol/l), de nem koronáriabeteg japán 75 év felettiek (átlagéletkor: 80 év) esetében az ezetimib-monoterápia is képes volt csökkenteni a kardiovaszkuláris események számát (12).

\section{Az idősek primer prevenciós koleszterin- csökkentő kezelése az ajánlásokban}

$A z$ idősek primer prevenciós statinkezelését mind az ESC/EAS, mind az amerikai (ACC/AHA) irányelv csak megfontolhatónak (Il.b ajánlás) (13) tartja. Az idősek lipidkezelése tekintetében az ESC/EAS korábbi, 2016os ajánlása proaktívabb volt, a fiatalabbakéhoz hasonló stratégiát javasolva (14) (pedig azóta nem jelent meg a koleszterincsökkentés hatástalanságát vagy ártalmát igazoló intervenciós tanulmány). Nem rendelkezik az ESC/EAS ugyanakkor határozottan arról, hogy mi legyen a diabéteszes és/vagy $60 \mathrm{ml} / \mathrm{min} / 1,73 \mathrm{~m}^{2}$ alatti eGFR-ü 75 év felettiek esetén követendő koleszterincsökkentő stratégia. Az irányelv szelleméböl az következik, hogy ilyenkor ugyanazok a célok érvényesek, mint fiatalabbak esetén. Az ACC/AHA-ajánlás konzervatívabb: 75 év feletti diabéteszesek esetén a korábban elkezdett statin folytatása csak megfontolandó (II.a ajánlás), indítása viszont csak megfontolható (II.b ajánlás), nem diabéteszes 76 és 80 év közöttieknél pedig koronária kalciumscoremeghatározást is megfontolhatónak tartanak a statinkezelés indikációjának szúkítésében (II.b ajánlás) (13).

\section{Az idősek koleszterincsökkentö kezelése és európai célértéke}

Az ESC/EAS a 75 év felettiek szekunder prevenciója vonatkozásában ugyanazt a szigorú - 1,4 mmol/l alatti 
- LDL-C-célértéket javasolja, annyi különbséggel, hogy bizonyos esetekben a statin óvatos titrálását ajánlják (1). Két tényező került nevesítésre e tekintetben: a vesekárosodás és a lehetséges gyógyszer-interakciók. (Megjegyzendő, hogy az atorvastatin nem kumulálódik érdemben $60 \mathrm{ml} / \mathrm{min} / 1,73 \mathrm{~m}^{2}$ alatti GFR-nél sem, és a mindennapi gyógyszer-interakciók közül leginkább az itraconazol és a clarithromycin jelent számottevő biztonsági kockázatot. A kalciumcsatorna-blokkolók és az amiodaron például nem szoktak $50 \%$-ot meghaladó atorvastatin vérszintemelkedést okozni, a voriconazol és HIV-ellenes terápia pedig a specialisták felségterülete. A rosuvastatin esetében fordított a helyzet: $60 \mathrm{ml} /$ $\mathrm{min} / 1,73 \mathrm{~m}^{2}$ alatti GFR-nél nem alkalmazható $40 \mathrm{mg}$ os dózis, illetve $30 \mathrm{ml} / \mathrm{min} / 1,73 \mathrm{~m}^{2}$ alatt egyáltalán nem adható a szer; viszont ritka a más gyógyszerek okozta érdemi farmakokinetikai probléma - ilyen a [transzplantáció utáni] ciklosporinkezelés, amikor csak a csökkentett adagú fluvastatin nem kontraindikált.)

Az ACC/AHA időskorban kisebb adagokat tart megfontolandónak, „májfunkciós abnormitás” veszélyére hivatkozva (13). Ugyanakkor statin hepatopathiáról időseknél sem beszélhetünk, csak esetleges statin okozta májenzim-emelkedésről (15), aminek a jelentősége viszont leértékelődött az utóbbi időben; így az FDA a kezelés melletti májenzim-ellenőrzést 2012 óta nem javasolja (16).

\section{Gyógyszeres koleszterincsökkentés szívelégtelenségben}

Obszervációs és bizonyos kisebb randomizált vizsgálatok, illetve nagyobbak posthoc elemzése alapján korábban a statinok szívelégtelenséget javító hatása volt vélelmezhető. Ezt azonban az erre tervezett két nagy vizsgálat a GISSI HF (17) és a - mostanában rosszul csengő elnevezésü - CORONA (18) nem erősítette meg. A bevontak átlagos ejekciós frakciója $33 \%$, illetve $31 \%$ volt. A CORONA különösen tanulságos, mert valamennyi beteg ISZB-s volt (a GISSI HF esetében csak $40 \%$ ), s bár $10 \mathrm{mg}$ rosuvastatin csökkentette a hospitalizációk számát, sem az elsődleges - kombinált kemény kardiovaszkuláris - végpontesemények, sem a koronáriatörténések gyakorisága nem különbözött érdemlegesen, annak ellenére hogy mind az LDL-C, mind a CRP jelentősen csökkent (45, illetve 37\%-kal), s igen magas volt a vizsgálat statisztikai ereje (692 vs. 732 esemény). (A GISSI HF iszkémiás és nem iszkémiás alcsoportja között sem volt érdemi különbség.)

$\mathrm{Az}$ európai szívelégtelenség irányelv nem tanácsolja statin indítását, de iszkémiás eredet esetén annak további folytatását megfontolandónak (II.a ajánlás), más szövegkörnyezetben pedig megfontolhatónak (II.b ajánlás) tartja; a polifarmácia csökkentésére vonatkozó javaslatban pedig (14.3. táblázat) a statin elhagyását hozzák fel példaként (19). A 2018-as amerikai ACC/ AHA koleszterinkezelési irányelv alapján iszkémiás eredetủ csökkent EF-szívelégtelenségben is csak megfontolható (II.b ajánlás) a statin (13). Az ESC/EAS állásfoglalása ezekhez hasonló, de támogatóbb (1). E szerint szívelégtelenségben szenvedő betegek esetében a statinok rutinszerủ alkalmazása akkor nem ajánlott, ha egyéb indikáció (pl. koronáriabetegség) nem áll fenn, illetve mivel nincs ártalomra vonatkozó bizonyíték, szívelégtelenség megjelenése nem indokolja statinkezelés felfüggesztését.

Úgy tünik, hogy a - legalábbis HFrEF - szívelégtelen koronáriabetegek koronáriabetegsége más (keményebb) természetü, mint általában. Hasonló jelenséggel találkozunk krónikus veseelégtelenségben is.

\section{Gyógyszeres koleszterincsökkentés} krónikus veseelégtelenségben

Gyógyszeres koleszterincsökkentő stratégiák vesepótló kezelést nem igénylő

krónikus veseelégtelenség esetén

A Kidney Disease: Improving Global Outcomes (KDIGO) részéről még mindig a 2013-as ajánlás van érvényben (Kidney Disease), de az elmúlt évek evidenciái sem tették anakronisztikussá (20). A KDIGO szerint ha az eGFR $60 \mathrm{ml} / \mathrm{min} / 1,73 \mathrm{~m}^{2}$ alatti, de vesepótló kezelés nem szükséges, 50 éves kor felett statin, illetve statin + ezetimib alkalmazása javasolt (1.A ajánlás), eGFR $\geq 60 \mathrm{ml} / \mathrm{min} / 1,73 \mathrm{~m}^{2}$ esetén pedig statinkezelés (1.B ajánlás); vesepótló kezelésre nem szoruló 18-49 éves krónikus vesebeteg (CKD) esetén statin csak szívinfarktus, koronáriarevaszkularizáció vagy stroke után indokolt, illetve ha a globális kardiovaszkuláris kockázat felmérése során a Framingham szerinti kockázat $10 \%$ feletti (2.A ajánlás).

A KDIGO javasolta koleszterincsökkentő dózisok - a statin + ezetimib kombináció kivételével - mérsékeltek, arra hivatkozva, hogy a nagyobb adagú statin biztonságossága CKD esetén nem kellően igazolt. ( $A$ TNT-vizsgálatban a nagy adagú atorvastatin mellett a CKD-betegek esetén a súlyos mellékhatások gyakorisága nagyobb volt, mint kisebb dózis esetén, annak ellenére, hogy atorvastatinnál - mint fentebb említettük - nem kell számolni az exkréció csökkenésével [21]; a jelenség hátterében inkább az áll, hogy CKD esetén a szövődményekre hajlamosító egyéb komorbiditás és polifarmácia gyakoribb.)

Az ESC/EAS szerint a 30-59 ml/min/1,73 $\mathrm{m}^{2}$ közötti eGFR-üek nagy kockázatúnak, a $30 \mathrm{ml} / \mathrm{min} / 1,73 \mathrm{~m}^{2}$ alatti eGFR-üek pedig igen nagy kockázatúnak minősülnek (életkori megkötés nélkül), ennek megfelelő lipidkezelési stratégiával és célértékekkel (1-3. táblázat) (1). A kockázati megkülönböztetésnek az az indoka, hogy $45 \mathrm{ml} / \mathrm{min} / 1,73 \mathrm{~m}^{2}$ alatt rohamosan esni kezd az $1 \mathrm{mmol} / \mathrm{l}$ LDL-C-csökkenésből adódó relatív kardiovaszkuláris kockázat mérséklődésének a mértéke (a relatív rizikó 45-59 eGFR-nél: 0,76, [0,70-0,81]; 30-44 eGFR-nél: 0,85 [0,75-0,96]; eGFR <30 esetén, dialízis nélkül: 0,85 [0,71-1,02] és dializáltakon: 0,94 [0,79-1,11]), 
1. TÁBLÁZAT. Az Európai Kardiológiai Társaság és az Európai Ateroszklerózis Társaság (ESC/EAS) 2019-es dyslipidaemia irányelveinek a koleszterincsökkentő kezelés javallatára vonatkozó LDL-C-értékei a kardiovaszkuláris kockázati kategóriák szerint (1)

\begin{tabular}{|c|c|c|c|c|c|c|}
\hline \multirow[t]{2}{*}{ Kockázat } & \multicolumn{6}{|c|}{ LDL-koleszterin (mmol/l) } \\
\hline & $<1,4$ & $\begin{array}{l}1,4- \\
1,79\end{array}$ & $\begin{array}{l}1,8- \\
2,59\end{array}$ & $\begin{array}{l}2,6- \\
2,99\end{array}$ & $\begin{array}{l}3,0- \\
4,89\end{array}$ & $\geq 4,9$ \\
\hline \multicolumn{7}{|l|}{ Alacsony } \\
\hline \multicolumn{7}{|l|}{ Mérsékelt } \\
\hline \multicolumn{7}{|l|}{ Nagy } \\
\hline \multicolumn{7}{|l|}{$\begin{array}{l}\text { Igen nagy, } \\
\text { primer } \\
\text { prevencióban }\end{array}$} \\
\hline \multirow[t]{3}{*}{$\begin{array}{l}\text { Igen nagy, } \\
\text { szekunder } \\
\text { prevencióban }\end{array}$} & * & & & & & \\
\hline & \multicolumn{6}{|c|}{ Életmódkezelés } \\
\hline & \multicolumn{6}{|c|}{$\begin{array}{l}\text { Életmódkezelés, ha nem elegendő, koleszte- } \\
\text { rincsökkentő gyógyszer megfontolandó }\end{array}$} \\
\hline * & \multicolumn{6}{|c|}{$\begin{array}{l}\text { Életmódkezelés mellett koleszterincsökkentö } \\
\text { gyógyszer megfontolandó }\end{array}$} \\
\hline & \multicolumn{6}{|c|}{$\begin{array}{l}\text { Életmódkezelés és egyidejüleg koleszterin- } \\
\text { csökkentő gyógyszer }\end{array}$} \\
\hline
\end{tabular}

2. TÁBLÁZAT. Az Európai Kardiológiai Társaság és az Európai Ateroszklerózis Társaság (ESC/EAS) 2019-es dyslipidaemia irányelveinek LDL-C-célértékei kockázati kategóriák szerint (1). Recidív esemény*: maximálisan tolerált statinterápia ellenére két éven belül újabb vaszkuláris esemény

\begin{tabular}{l|l|l}
\hline Recidív esemény* & $<1,0 \mathrm{mmol} / \mathrm{l}$ & megfontolható \\
\hline Igen nagy KV-kockázat & $<1,4 \mathrm{mmol} / \mathrm{l}$ & $\begin{array}{l}+>50 \% \text {-os } \\
\text { csökkentés }\end{array}$ \\
\hline Nagy KV-kockázat & $<1,8 \mathrm{mmol} / \mathrm{l}$ & \\
\hline Mérsékelt KV-kockázat & $<2,6 \mathrm{mmol} / \mathrm{l}$ & megfontolandó
\end{tabular}

3. TÁBLÁZAT. A koleszterincsökkentés stratégiája az Európai Kardiológiai Társaság és az Európai Ateroszklerózis Társaság (ESC/EAS) szerint (válogatás és kiemelés általam) (1). O: az ajánlás erősségének osztálya; Sz: a bizonyítékok erősségének a szintje. Az osztály az ajánlás erősségét jelzi, ami szerint valamely eljárás I: ajánlott/javasolt. A szint a bizonyítékok minőségét jelzi: A: több randomizált kontrollált vizsgálatból vagy metaanalízisből származó adatok, B: egy randomizált kontrollált vizsgálatból vagy több nagy, nem randomizált vizsgálatból származó adat.

\section{Ajánlások}

Nagy intenzitású statin adása javasolt a rizikóstátusznak megfelelő célérték eléréséhez

Ha a maximálisan tolerálható statinnal a cél nem elérhető, ezetimibbel kell kombinálni a statint

Szekunder prevencióban igen nagy kockázat esetén, ha a cél nem elérhető maximálisan tolerálható statin + ezetimib adásával PCSK9-gátlóval történő kiegészítés javasolt miközben az abszolút rizikó emelkedik (22). Emiatt a romló vesefunkcióval párhuzamosan (még) intenzívebb koleszterincsökkentés indokolt (1). Ez a szemlélet tehát bizonyos mértékig ellentétben áll a KDIGO konzervatívizmusával (20).

Gyógyszeres koleszterincsökkentő stratégiák vesepótló-kezelést igénylők esetében Míg a KDIGO nem foglal állást a krónikus dialíziskezelésre szorulók lipidcsökkentő kezelése mellett vagy az ellen (20), ESC/EAS nem javasol statinkezelést ateroszklerotikus betegséggel nem terhelt dializáltak esetén (az ezetimib kombináció explicite nem szerepel ilyen kontextusban), de az előzőleg megkezdett koleszterincsökkentő gyógyszerelés folytatása megfontolandó (1). Ennek az a magyarázata, hogy hemodializáltakon két nagy statinos vizsgálat is sikertelen lett $(23$, 24). A kiábrándító adatokhoz hozzájárulhat, hogy ezen betegek esetében - mint arra Császár Albert profeszszor nemrégiben felhívta a figyelmet (25) - a koleszterinfelszívódás fokozott (26). Ezzel összefüggésben, a nem „felszívó típusú” tercilis alcsoport esetében a 20 mg atorvastatin is csökkentette a major kardiovaszkuláris események számát (27). Ez fókuszba helyezi az ezetimib kombináció jelentőségét dializáltakon.

\section{A krónikus veseelégtelenségben választott koleszterincsökkentő kezelést befolyásoló tanulmányok}

A 20 mg simvastatin + 10 mg ezetimib kombinációt placebóval átlagosan 4,9 évig összehasonlító SHARP 9270 3-5. stádiumú CKD betegének medián eGFR-értéke $26,6 \mathrm{ml} / \mathrm{min} / 1,73 \mathrm{~m}^{2}$ volt, 2100 diabéteszben is szenvedett, s 3023 beteg (a populáció 33\%-a) már a bevonáskor dialíziskezelést igényelt (28). A kardiovaszuláris rizikó $1 \mathrm{mmol} / \mathrm{l}$ LDL-C-csökkenésre extrapolált relatív mérséklődése a különböző súlyossági - 3-4 és nem dializált 5. stádiumú CKD - csoportokban a nem vesebetegekhez hasonló, 21-25\% mértékű volt, miközben a súlyos mellékhatások sem voltak gyakoribbak, mint placebo mellett. A dializált szubpopulációban - a koleszterinfelszívódást is gátló kombináció ellenére - az LDL-C csak 0,60 mmol/l-rel volt alacsonyabb az aktív ágon, míg a nem dializáltak esetében ez a különbség 0,96 mmol/l lett. Ennek ellenére nem volt statisztikailag szignifikáns különbség a két csoport között a hatékonyság tekintetében.

CKD esetén az is figyelembe veendő - a rosuvastatin fentebb említett eGFR szerinti dóziskorrekciója mellett -, hogy az intenzív atorvastatin a rosuvastatinnál nefroprotektívabbnak bizonyult diabéteszes vesebetegeken (29).

\section{Koleszterincsökkentés alacsony kockázatúak esetén}

Egyedülálló újdonság, hogy az ESC/EAS a koleszterincsökkentő gyógyszeres kezelés javallati körét az 
alacsony kockázatúak felé is kiterjesztette, így mélyen medián alatti, 3,0 mmol// LDL-C-től megfontolandó lett a gyógyszeres kezelés, ha az életmódkezelés nem elegendő (1). Az életmódkezelés pedig általában nem elegendő a kockázat érdemi csökkentéséhez, mivel például a koleszterinszintet (vagy a vérnyomást) csak mérsékelten tudja befolyásolni; tehát akinek 3,0 mmol/l feletti az LDL-C szintje, valószínüleg afeletti is marad életmódkezelés mellett is. Vagy, ha valaki leszokik a dohányzásról, évek telnek el, míg a rizikó mérséklődik, de időközben az illető ennyivel idősebb lett. Tehát az életmódkezelés - bár nagyon is fontos módon, de - inkább kiegészíti, mint helyettesíti a gyógyszereset.

$A z$ irányelv alacsony kockázatúak gyógyszeres kezelése felé történő nyitása nem nyugszik ugyan erős bizonyítékokon (direkt ilyen populációra különösen nehéz lenne klinikai vizsgálatot tervezni és eredményesen lefolytatni és egy nem megfelelő tanulmány több negatív, mint pozitív következménnyel járna), de a koleszterincsökkentés minden ízében egybecsengő hatásossága és biztonságossága is elfogadhatóvá, sőt egyesek számára követendővé teszi ezen javaslatot. Figyelembe kell azt is venni, hogy bár a tízéves abszolút haszon alacsony kockázatúaknál alacsony, az élethosszra vetített kardiovaszkuláris rizikó szinte mindenkinél magas (30). Másik oldalról nézve a minél korábban elkezdett koleszterincsökkentő gyógyszeres kezelés mellett szól, hogy a klinikai vizsgálatok betegeinek életkori tartományában elkezdett kezelés során $1 \mathrm{mmol} / \mathrm{L}$ LDL-C-csökkentéssel átlagban 21\%-os KV-esemény redukció érhető el, míg ha genetikai polimorfizmusokkal kapcsolatos (természetesen létrejövő) az $1 \mathrm{mmol} / \mathrm{l}$-rel alacsonyabb LDL-C, a KV-kockázat 50\%-ot meghaladó mértékben kisebb (31)!

\section{Milyen intervenciós bizonyítékai vannak az} alacsony kockázatúak statinkezelésének?

A nagy lipidvizsgálatok alacsony kockázatú alcsoportjaiból készített megbízható metaanalízis legalább akkora relatív kockázatcsökkenést jelzett, mint a magasabb rizikójúak esetén (32). Továbbá több, célzottan mérsékelt kockázatú, nem hypercholesterinaemiás egyénekre tervezett vizsgálat is (JUPITER, ASCOT-LLA, HOPE-3) igazolta az LDL-C-csökkenéssel arányos kemény KV-eseménygyakoriság mérséklődését (33-35). (A JUPITER során elért, 50\%-ot közelítő kockázatcsökkenés nemcsak a lipidszerekkel, hanem általában a gyógyszerekkel, sőt akármilyen KV-módszerrel elért legnagyobb érték azóta is. Ráadásul a mellékhatások - többek között a máj és izombántalommal kapcsolatosak - sem lettek gyakoribbak.)

Biztonságossági aggályt jelent ugyanakkor, hogy bár a statinok esetén a kockázat:haszon arány az egyéb kezelési formákhoz képest kiemelkedően jó (15), az évtizedeken át az egészségesek szedte szerek potenciális ártalmai felértékelődnek, különösen a médiában. Ezek alapján a gyakorlatban mikor lehet indokolt ala-
4. TÁBLÁZAT. A SCORE (Systematic Coronary Risk Estimation) alapján számolt kardiovaszkuláris kockázatot növelő tényezők (1)

Kardiovaszkuláris betegség a családi előzményben (férfiak: $<55$ év és nők: $<60$ év)

Társadalmi nélkülözés

Pszichoszociális stressz, beleértve az életerő kimerülését

Súlyos pszichiátriai rendellenességek

Elhízás

Fizikai inaktivitás

Nem alkoholos zsírmáj-betegség

Krónikus vesebetegség

Balkamra-hipertrófia

Pitvarfibrilláció

Obstruktív alvási apnoeszindróma

Krónikus immunmediált gyulladásos betegségek

Humán immunhiány vírusfertőzés kezelése

csony kockázatúak gyógyszeres koleszterincsökkentő kezelése? A 4,9 mmol/l-t (valamikor is) elérő LDL-C esetén önmagában (egyébként alacsony kockázatnál) is egyértelmüen ajánlott (I. ajánlás) felnőttkorban - a várandóságot és az azt megelőző időszakot leszámítva $(1,13)$. (Ha familiáris hypercholesterinaemia igazolódik családtagnál, az érintett gyermek statinkezelése 8-10 éves kortól az ESC/EAS szerint megfontolandó, az ACC/AHA alapján egyértelműen szükséges.) Egyébként jobbára 40 éves kor az a határ, amikor szóba jön statin. Ez harmonizál az ACC/AHA-ajánlással (13). A kezelés mellett szól, ha az ESC/EAS szerint számba vett, a SCORE alapján számolt kardiovaszkuláris kockázatot fokozó körülmény áll fenn (4. táblázat). Szempont lehet - különösen, ha a családi előzmény korai ateroszklerotikus betegséggel terhelt - a magasabb koleszterin (LDL-C: 4,2-4,8) vagy Lp(a) szint is. (Utóbbi egy alapvetően genetikailag meghatározott proateroszklerotikus tényező, ami a népesség kb. 30\%-ánál 25 $\mathrm{mg} / \mathrm{dl}$ feletti, ahol lineáris lesz a kapcsolat a koncentráció és kockázat között) (36). Az eszközös vizsgálatok a carotis vagy femoralis plakk ultrahangos kimutatása, illetve a koronária-kalciumscore, a boka-kar index vagy pulzushullám terjedési sebességmérés - pozitivitása alacsony kockázat mellett ritka (ezek mérsékelt kockázat esetén lehetnek inkább rizikófinomítók) $(37,38)$.

Megjegyzendő, hogy a szintén érvényben lévő európai prevenciós irányelv nem javasolja a kiegészítő biomarker vagy eszközös vizsgálatok rutinszerü végzését (37).

\section{Következtetések}

Az európai dyslipidaemiaajánlás javallati köre 2019-ben, egyedi módon az alacsony kockázatúak irányában kiterjedt, egyébként - az amerikaihoz hasonlatosan - a 75 év felettieknél szükült, a szívelégtelen vagy veseelégtelen betegek esetén pedig érdemben nem változott. 


\section{Nyilatkozat \\ A szerző kijelenti, hogy az összefoglaló közlemény megírásával kapcsolatban nem áll fenn támogatás.}

Irodalom

1. Mach F, Baigent C, Catapano AL, et al. 2019 ESC/EAS Guidelines for the management of dyslipidaemias: lipid modification to reduce cardiovascular risk. Eur Heart J 2020; 41: 111-188.

https://doi.org/10.1093/eurheartj/ehz455

2. Cholesterol Treatment Trialists' Collaboration. Efficacy and safety of statin therapy in older people: a meta-analysis of individual participan data from 28 randomised controlled trials. Lancet 2019; 393: 407-415 https://doi.org/10.1016/S0140-6736(18)31942-1

3. Iwere RB, Hewitt J. Myopathy in older people receiving statin therapy: a systematic review and meta-analysis. Br J Clin Pharmacol 2015; 80: 363-71. https://doi.org/10.1111/bcp.12687

4. Bach RG, Cannon CP, Giugliano RP, et al. Effect of simvastatinezetimibe compared with simvastatin monotherapy after acute coronary syndrome among patients 75 years or older: a secondary analysis of a randomized clinical trial. JAMA Cardiol 2019; 4: 846-854.

https://doi.org/10.1001/jamacardio.2019.2306

5. Prospective Studies Collaboration, Lewington S, Whitlock G, Clark $\mathrm{R}$, et al. Blood cholesterol and vascular mortality by age, sex, and blood pressure: a meta-analysis of individual data from 61 prospective stud ies with 55,000 vascular deaths. Lancet 2007; 370: 1829-39. https://doi org/10.1016/S0140-6736(07)61778-4

6. Curb JD, Abbott RD, Rodriguez BL, et al. Prospective association between low and high total and low-density lipoprotein cholesterol and coronary heart disease in elderly men. J Am Geriatr Soc 2004; 52: 1975 1980. https://doi.org/10.1111/j.1532-5415.2004.52551.x

7. Ravnskov U, Diamond DM, Hama R, et al. Lack of an association or an inverse association between low-density-lipoprotein cholestero and mortality in the elderly: a systematic review. BMJ Open 2016; 6 : e010401. https://doi.org/10.1136/bmjopen-2015-010401

8. Rodriguez F, Maron DJ, Knowles JW, et al. Association Between Intensity of Statin Therapy and Mortality in Patients With Atherosclerotic Cardiovascular Disease. JAMA Cardiol 2017; 2: 47-54.

https://doi.org/10.1001/jamacardio.2016.4052

9. Bajnok L. Időseknek statin, primer prevencióban? Hypertonia és Nephrologia 2019; 23: 4-7. https://doi.org/10.33668/HN.23.001

10. A Clinical Trial of STAtin Therapy for Reducing Events in the Elderly (STAREE); ClinicalTrials.gov Identifier: NCT02099123. Last Update Posted: March 12, 2019; Ellenőrizve: 2020. 08. 13

11. Statins In The Elderly (SITE). ClinicalTrials.gov Identifier: NCT02547883. Last Update Posted: February 7, 2020. Ellenőrizve: 2020. 08. 13.

12. Ouchi Y, Sasaki J, Arai H, et al. Ezetimibe Lipid-Lowering Trial on Prevention of Atherosclerotic Cardiovascular Disease in 75 or Older (EWTOPIA 75): A Randomized, Controlled Trial. Circulation 2019; 140: 992-1003. https://doi.org/10.1161/CIRCULATIONAHA.118.039415

13. Grundy SM, Stone NJ, Bailey AL, et al. 2018 AHA/ACC/AACVPR/ AAPA/ABC/ACPM/ADA/AGS/APhA/ASPC/NLA/PCNA Guideline on the Management of Blood Cholesterol: Executive Summary: A Report of the American College of Cardiology/American Heart Association Task Force on Clinical Practice Guidelines. J Am Coll Cardiol 2018. pii: S0735 1097(18)39033-8. https://doi.org/10.1016/j.jacc.2018.11.002

14. Catapano AL, Graham I, De Backer G, et al. 2016 ESC/EAS Guidelines for the Management of Dyslipidaemias: The Task Force for the Management of Dyslipidaemias of the European Society of Cardiology (ESC) and European Atherosclerosis Society (EAS) Developed with the special contribution of the European Assocciation for Cardiovascular Prevention \& Rehabilitation (EACPR). Eur Heart J 2016; 37: 2999-3058. https://doi.org/10.1093/eurheartj/ehw272

15. Collins R, Reith C, Emberson J, et al. Interpretation of the evidence for the efficacy and safety of statin therapy. Lancet 2016; 388: 2532 2561. https://doi.org/10.1016/S0140-6736(16)31357-5

16. Food and Drug Administration. FDA drug safety communication: important safety label changes to cholesterol lowering statin drugs. Available at: http: //www.fda.gov/drugs/drugsafety/ucm293101.htm Ellenőrizve: 2020. 08.13.

17. Tavazzi L, Maggioni AP, Marchioli R, et al. Effect of rosuvastatin in patients with chronic heart failure (the GISSI-HF trial): a randomised, double-blind, placebo-controlled trial. Lancet 2008; 372: 1231-39. https://doi.org/10.1016/S0140-6736(08)61240-4

18. Kjekshus J, Apetrei E, Barrios V, et al. Rosuvastatin in older patients with systolic heart failure. N Engl J Med 2007; 357: 2248-61. https://doi. org/10.1056/NEJMoa0706201

19. Ponikowski P, Voors AA, Anker SD, et al. 2016 ESC Guidelines for the diagnosis and treatment of acute and chronic heart failure: The Task Force for the diagnosis and treatment of acute and chronic heart failure of the European Society of Cardiology (ESC) Developed with the special contribution of the Heart Failure Association (HFA) of the ESC. Eur Heart J 2016; 37: 2129-2200. https://doi.org/10.1093/eurheartj/ehw128 20. Kidney Disease: Improving Global Outcomes (KDIGO) Lipid Work
Group. KDIGO Clinical Practice Guideline for Lipid Management in Chronic Kidney Disease. Kidney inter, Suppl 2013; 3: 259-305.

https://doi.org/10.1038/kisup.2013.42

21. Shepherd J, Kastelein JJP, Bittner V, et al. Intensive Lipid Lowering With Atorvastatin in Patients With Coronary Heart Disease and Chronic Kidney Disease: The TNT (Treating to New Targets) Study. JACC 2008; 51: 1448-1454. https://doi.org/10.1016/j.jacc.2007.11.072

22. Cholesterol Treatment Trialists' Collaboration, Herrington WG, Emberson J, et al. Impact of renal function on the effects of LDL cholesterol lowering with statin-based regimens: a meta-analysis of individual participant data from 28 randomised trials. Lancet Diabetes Endocrinol 2016; 4: 829839. https://doi.org/10.1016/S2213-8587(16)30156-5

23. Wanner C, Krane V, Marz W, et al; German Diabetes and Dialysis Study Investigators. Atorvastatin in patients with type 2 diabetes mellitus undergoing hemodialysis. N Engl J Med 2005; 353: 238-248.

https://doi.org/10.1056/NEJMoa043545

24. Fellström BC, Jardine AG, Schmieder RE, et al; AURORA Study Group. Rosuvastatin and cardiovascular events in patients undergoing hemodialysis. N Engl J Med 2009; 360: 1395-1407.

https://doi.org/10.1056/NEJMoa0810177

25. Császár A statin és az ezetimib kombinációjának új vetületei. Metabolizmus 2020; 18: 106-108.

26. Rogacev KS, Pinsdorf $T$, Weingärtner $O$, et al. Cholesterol synthesis, cholesterol absorption, and mortality in hemodialysis patients. Clin J Am Soc Nephrol 2012; 7: 943-8. https://doi.org/10.2215/CJN.05170511

27. Silbernagel G, Fauler G, Genser B, et al. Intestinal cholesterol absorption, treatment with atorvastatin, and cardiovascular risk in hemodialysis patients. J Am Coll Cardiol 2015; 65: 2291-2298.

https://doi.org/10.1016/j.jacc.2015.03.551

28. Baigent $C$, Landray MJ, Reith $C$ et al. The effects of lowering LDL cholesterol with simvastatin plus ezetimibe in patients with chronic kid ney disease (Study of Heart and Renal Protection): a randomised placebo-controlled trial. Lancet 2011; 377: 2181-92.

https://doi.org/101016/S0140-6736(11)60739-3

29. de Zeeuw D, Anzalone DA, Cain VA, et al. Renal effects of atorvastatin and rosuvastatin in patients with diabetes who have progressive renal disease (PLANET I): a randomised clinical trial. Lancet Diabetes Endocrinol 2015; 3: 181-190.

https://doi.org/10.1016/S2213-8587(14)70246-3

30. Finegold JA, ShunShin MJ, Cole GD, et al. Distribution of lifespan gain from primary prevention intervention. Open Heart 2016; 3: e000343. https://doi.org/10.1136/openhrt-2015-000343

31. Ference BA, Majeed M, Penumetcha R, et al. Effect of Naturally Random Allocation to Lower Low-Density Lipoprotein Cholesterol on the Risk of Coronary Heart Disease Mediated by Polymorphisms in NPC1L1, HMGCR, or Both: A $2 \times 2$ Factorial Mendelian Randomization Study. J Am Coll Cardiol 2015; 65: 1552-61.

https://doi.org/10.1016/j.jacc.2015.02.020

32. Cholesterol Treatment Trialists' (CTT) Collaborators, Mihaylova B, Emberson J, et al. The effects of lowering LDL cholesterol with statin therapy in people at low risk of vascular disease: meta-analysis of individual data from 27 randomised trials. Lancet 2012; 380: 581-590. https://doi.org/10.1016/S0140-6736(12)60367-5

33. Ridker PM, Danielson E, Fonseca FA, et al. Rosuvastatin to prevent vascular events in men and women with elevated $\mathrm{C}$ reactive protein. $\mathrm{N}$ Engl J Med 2008; 359: 2195-207.

https://doi.org/10.1056/NEJMoa0807646

34. Sever PS, Dahlöf B, Poulter NR et al. Prevention of Coronary and Stroke Events With Atorvastatin in Hypertensive Patients Who Have Average or Lower-Than-Average Cholesterol Concentrations, in the AngloScandinavian Cardiac Outcomes Trial - Lipid Lowering Arm (ASCOTLLA): A Multicentre Randomised Controlled Trial. Lancet 2003; 361 1149-58. https://doi.org/10.1016/S0140-6736(03)12948-0

35. Yusuf S, Bosch J, Dagenais G, et al.; HOPE-3 Investigators. Cho lesterol lowering in intermediate risk persons without cardiovascular disease. N Engl J Med 2016; 374: 2021-2031.

https://doi.org/10.1056/NEJMoa1600176

36. Tsimikas S. J Am Coll Cardiol. A Test in Context: Lipoprotein(a): Diagnosis, Prognosis, Controversies, and Emerging Therapies 2017; 69 692-711. https://doi.org/10.1016/j.jacc.2016.11.042

37. Piepoli MF, Hoes AW, Agewall S, et al. 2016 European Guidelines on cardiovascular disease prevention in clinical practice: The Sixth Joint Task Force of the European Society of Cardiology and Other Societies on Cardiovascular Disease Prevention in Clinical Practice. Eur Heart J 2016; 37: 2315-81. https://doi.org/101093/eurheartj/ehw106

38. Nasir K, Bittencourt MS, Blaha MJ, et al. Implications of Coronary Artery Calcium Testing Among Statin Candidates According to American College of Cardiology/American Heart Association Cholesterol Management Guidelines: MESA (Multi-Ethnic Study of Atherosclerosis). J Am Coll Cardiol 2015; 66: 1657-68.

https://doi.org/10.1016/j.jacc.2015.07.066 